\title{
Did Dietary Addition of Dried Periphyton Improved Growth Performance and Feed Utilization of Nile Tilapia \\ Rokia S. Saleh ${ }^{1}$, Mohamed, S. Hassaan, Magdy A. Soltan ${ }^{1}$, Ahmed A. Radwan ${ }^{1}$ \\ ${ }^{1}$ Animal production department, Faculty of Agriculture, Benha University.
}

\begin{abstract}
A 60-day feeding trial was carried out to evaluate the effect of dried periphyton supplementation on growth performance, feed utilization and proximate analysis of chemical composition in Nile tilapia, Oreochromis niloticus. Five diets (isonitrogenous and isocaloric) containing five levels of dried periphyton $0 \mathrm{~g}$ (diet 1 , control), $2.5 \mathrm{~g}$ (diet 2), $5 \mathrm{~g}$ (diet 3), $7.5 \mathrm{~g}$ (diet 4) and $10 \mathrm{~g}$ (diet 5) $\mathrm{kg}^{-1}$ diet were formulated. At the end of trial, the highest wight gain, specific growth rate, survival rate and protein efficiency ratio were recorded by fish fed diet 4 and diet 5 which supplemented with 7.5 and $10 \mathrm{~g}$ dried periphyton $\mathrm{kg}^{-1}$. No significant differences $(\mathrm{P}>0.05)$ were found in all chemical composition; dry matter, crude protein, crude lipid and ash content of tilapia fed different level of dried periphyton. The obtained results suggested that the best level of dietary dried periphyton in Nile tilapia feed was $7.5 \mathrm{~g}$ or $10 \mathrm{~g} \mathrm{~kg}^{-1}$ diet as a feed additive to promote growth.
\end{abstract}

Key words: Periphyton, Growth, Nile Tilapia, survival

\section{Introduction}

Sector of aquaculture production should be enhanced in order to increase the human population, especially food-fish contribution from capture fisheries is levelled off (FAO, 2018). The growing demand of aquatic animal leads to the intensification of the culture practices, overdrawing stressors for fish and thus magnifying the risk of diseases (Hassaan et al., 2020). Feed additives have been an increasingly a well-known management technique in aquaculture production systems, where abundant supplements have established an efficiency to enhance the fish immune response or controlling the severity of infections under intensification (MenanteauLedouble et al., 2015; Hassaan et al., 2020). The perfect feed ingredients used in fish feed shouldensure growth, immunity and health promoting factors to achieve a great effect on the farm net gain. Various studies have been cleared over the years to extend solutions to these negative effects such as the use of antibiotics, hormones or other chemotheraby (Fawole et al., 2016). Periphyton refers to the entire complex of attached aquatic biota on submerged substrates comprise phytoplankton, zooplankton, benthic organisms and detritus (Azim et al., 2005; van Dam et al., 2002) and forms an additional food in aquatic production systems. Many trials in fish culture ponds have demonstrated the utility of submerged substrate in enhancing the fish production (Asaduzzaman et al., 2009; Azim et al., 2005; Keshavanath et al., 2002). Numerus reports are offered about beneficial effects of algae products as a dietary ingredient in Aquatic animal (Ju et al., 2009; Kuhn et al., 2010), but no information is available to support the dietary effect of periphyton. Thus, this study investigates the effects of dried periphyton on growth, survival and chemical composition of Nile tilapia. activities in $\mathrm{P}$. monodon juveniles.

\section{Materials and methods}

1.1. Source of periphyton and proximate composition

The dried periphyton was kindly provided by farm of National Institute of Oceanography and Fisheries (NIOF), Egypt. The major community of periphyton obtained from NIOF farm are chlorophytes, cyanophytes, dinoflagellates, diatoms, euglenophytes, protozoa and detritus. Chemical composition of dried periphyton (Table 1) was estimated according to AOAC (1995).

Table 1. Proximate chemical composition $\mathrm{g} \mathrm{kg}^{-1}$ of dried periphyton

\begin{tabular}{lc}
\hline Items & Chemical composition \\
\hline Moisture & 70.20 \\
Crude protein & 200.13 \\
Crude lipid & 44.52 \\
Ash & 412.31 \\
Crude fiber & 70.26 \\
Nitrogen free extract & 260.40 \\
\hline
\end{tabular}

\subsection{Experimental design and culture technique}

A one-way experiment was designed to investigate the effect of dried periphyton supplementation on performance of growth, nutrient utilization and chemical proximate analysis of whole-body fish of Nile tilapia (Oerocromis niloticus). O. niloticus were obtained from private farm, Kafer-Elshekh Governorate, Egypt. Fish after arrived were 
acclimated to the experimental conditions for two weeks at the laboratory of fish at Faculty of Agriculture, Benha University in five tanks $\left(0.5 \mathrm{~m}^{3}\right.$ for each). During the acclimation period, fish were fed a commercial feed (30\% crude protein and $6 \%$ lipid) at a rate of $4 \%$ of total biomass, which provided of equal rations at 09:00 am and 3:00 pm for 2 weeks. After the acclimatization, 25 fish with an average weight of $(6.82 \pm 0.06 \mathrm{~g})$ were randomly allocated into the experimental circular plastic tanks $\left(0.5 \mathrm{~m}^{3}\right.$ for each) representing the five treatments studied with three replicates.

All tanks were supplied with fresh water and housed within an artificially illuminated room. About $20 \%$ of water volume in each tank was daily replaced by aerated fresh water after removing the accumulated excreta. A photoperiod of 12-h light, 12-h dark (08:00 20:00 h) was used fluorescent ceiling lights supplied the illumination. During the 60-day experimental period, all groups of fish were hand-fed with the respective diet to apparent satiation twice daily at 09:00 am and 3:00 pm. Feed intake was calculated and expressed as the total feed intake in whole period of experiment per fish. All tested water quality criteria (temperature, $\mathrm{pH}$ value,
DO and total amonia) were suitable and within the acceptable limits for rearing Nile tilapia $O$. niloticus fingerlings (Boyd, 1990). These positive findings in water quality criteria related with good growth performance since there were no mortalities during whole period of feeding experiment.

\subsection{Diets}

Practical ingredients (free fishmeal) were used to formulate the five experimental diets, which were isonitrogenous and isocaloric (Table 2). Diet 1 was considered the control, was without dried periphyton supplementation. Dried periphyton was added to the other four diets at levels $2.5 \mathrm{~g}$ (diet 2), $5 \mathrm{~g}$ (diet 3), $7.5 \mathrm{~g}$ (diet 4) and $10 \mathrm{~g}$ (diet 5) $\mathrm{kg}^{-1}$ diet. Diets were prepared to confirm the control diet. Periphyton was prepared in National Institute of Oceanography and Fisheries, Cairo Governorate, Egypt. Periphyton was added to powered in a different proportion as in the Table 2 . All dry ingredients were thoroughly mixed with soybean oil, and vitamins and minerals mixture, and then passing the mixed feed through a laboratory pellet mill (2-mm die) in National Institute of Oceanography and Fisheries, Cairo Governorate, Egypt (CMP California Pellet Mill, San Francisco, CA, USA), and stored at $-20^{\circ} \mathrm{C}$ until used.

Table 2. Ingredient and proximate composition of the experimental diets ( $\mathrm{g} \mathrm{kg}^{-1}$ dry diet)

\begin{tabular}{lccccc}
\hline \multirow{2}{*}{ Ingredients } & \multicolumn{5}{c}{ Experimental diets } \\
\cline { 2 - 5 } & Diet 1 & Diet 2 & Diet 3 & Diet 4 & Diet 5 \\
\hline Soybean meal & 530 & 530 & 530 & 530 & 530 \\
Corn gluten & 100 & 100 & 100 & 100 & 100 \\
Yellow corn & 190 & 190 & 190 & 190 & 190 \\
Wheat bran & 100 & 98.5 & 95 & 95 & 90 \\
Dried periphyton & 0 & 2.5 & 5.0 & 7.5 & 10 \\
Soybean oil & 40 & 40 & 40 & 40 & 40 \\
Vita \& M ${ }^{1}$ & 40 & 40 & 40 & 40 & 40 \\
\hline Chemical analysis & & & & 89.85 \\
Dry matter & 89.92 & 89.85 & 89.83 & 89.84 & 32.60 \\
Crude protein & 32.54 & 32.55 & 32.56 & 32.58 & 5.52 \\
Crude lipid & 5.49 & 5.49 & 5.51 & 5.52 & 4.56 \\
Ash & 4.21 & 4.29 & 4.38 & 4.47 & 57.32 \\
Total carbohydrate & 57.56 & 57.67 & 57.55 & 57.43 & 18.82 \\
GE $^{3}$ (MJ kg ${ }^{-1}$ ) & 18.87 & 18.85 & 18.84 & 18.83 & \\
\hline \multicolumn{1}{l}{ Vit }
\end{tabular}

${ }^{1}$ Vitamin and mineral mix (mg or g/ Kg diet): MnSO4, 40 mg; MgO, 10 mg; K2SO4, 40 mg; ZnCO3, 60 mg; KI, 0.4 mg; CuSO4, $12 \mathrm{mg}$; Ferric citrate, $250 \mathrm{mg}$; Na2SeO3, $0.24 \mathrm{mg}$; Co, $0.2 \mathrm{mg}$; retinol, $40000 \mathrm{IU}$; cholecalciferol, $4000 \mathrm{IU}$; $\alpha$-tocopherolacetate, $400 \mathrm{mg}$; menadione, $12 \mathrm{mg}$; thiamine, $30 \mathrm{mg}$; riboflavin, $40 \mathrm{mg}$; pyridoxine, $30 \mathrm{mg}$; cyanocobalamin, $80 \mathrm{mcg}$; nicotinic acid, $300 \mathrm{mg}$; folic acid, $10 \mathrm{mg}$; biotin, $3 \mathrm{mg}$; pantothenic acid, $100 \mathrm{mg}$; inositol, $500 \mathrm{mg}$; ascorbic acid, $500 \mathrm{mg}$. ${ }^{2}$ B. acidophullus was prepared to obtain $\left(1.47 \times 10^{7} \mathrm{CFU} \mathrm{kg}{ }^{-1}\right.$ approximately.

Total carbohydrate $=100-($ crude protein + lipid + ash $)$.

${ }^{3}$ Gross energy, calculated using gross calorific values of $23.63,39.52$ and $17.15 \mathrm{KJ} \mathrm{g}^{-1}$ for protein, fat and carbohydrate, respectively according to Brett (1973).

\subsection{Growth performance and feed utilization parameters}

Records of weight $(\mathrm{g})$ was estimated in all fish every 14 days during the experimental period. Growth performance parameters were measured by using the following equations:

Weight gain $(\mathrm{WG})=$ final weight $(\mathrm{g})-$ initial weight $(\mathrm{g})$; Specific growth rate (SGR): $\mathrm{SGR}=$
$\frac{\mathrm{LnW} 2-\mathrm{LnW} 1}{\mathrm{t}} \times 100$; Where: $\mathrm{Ln}=$ the natural $\log$

$\mathrm{W}_{1}=$ first fish weight $\mathrm{W}_{2}=$ the following fish weight in grams; $\mathrm{t}=$ period in days.

Feed conversion ratio was calculated by the equation: FCR = Feed ingested $(\mathrm{g}) /$ Weight gain $(\mathrm{g})$; Protein efficiency ratio $(\mathrm{PER})=$ Weight gain $(\mathrm{g}) /$ Protein ingested $(\mathrm{g})$

1.5. Chemical analysis of fish and experimental diets

The chemical composition of fish and diet samples were determined according to procedures of AOAC (1995). Dry matter (DM) was determined after drying 
the samples in an oven $\left(105^{\circ} \mathrm{C}\right)$ for $24 \mathrm{~h}$. Ash by incineration at $550{ }^{\circ} \mathrm{C}$ for $12 \mathrm{~h}$. Crude protein was determined by micro-Kjeldhal method, $\mathrm{N} \% \times 6.25$ (using Kjeltechauto analyzer, Model 1030, Tecator, Höganäs, Sweden) and crude fat by Soxhlet extraction with diethyl ether $\left(40-60^{\circ} \mathrm{C}\right)$.

\section{Statistical analysis}

All data were analyzed by using the software SAS, version 6.03 (Statistical Analysis System 1996). One-way analysis of variance (One-way ANOVA) was used to determine whether significant variation existed between the treatments. When overall differences were found, differences between means were tested by Duncan (1955) new multiple range test. All differences were considered significant at $\mathrm{P}<0.05$ and the results are presented as means with pooled standard error of the mean).

\section{Results}

\subsection{Growth performance of Nile tilapia as affected by different levels of dried periphyton}

As shown in Fig 1, the differences in body weight (BW) were observed after four weeks from the experiment start and increased as the feeding period continued. Results of the effect of different levels of dried periphyton on weight gain (WG) and specific growth rate (SGR) in Nile tilapia were presented in Table 3. As shown in this Table the results showed that fish fed the diet 1 (control) had the lowest significant (P $<0.01) \mathrm{WG}$ and SGR compared with fish fed the other diets. Fish fed diet 4 and diet 5 which supplemented with 7.5 and $10 \mathrm{~g}$ dried periphyton $\mathrm{kg}^{-1}$ recorded the higher WG, SGR, PER and best FCR compared with other treatments.

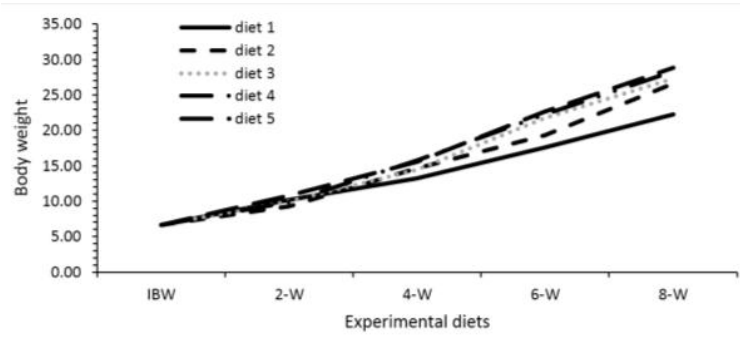

Fig. 1 Changes in final body weight means of experimental fish during the experiment period.

The Data of WG for fish fed different level of dried periphyton fitted a quadratic model (Fig. 2). Weight gain $(y)=0.0103 x^{2}-0.1444 x+1.717 ; R^{2}=0.8623$. According to these equations, the highest WG was recorded by fish fed diet 5 which supplemented $10 \mathrm{~g}$ dried periphyton $\mathrm{kg}^{-1}$.

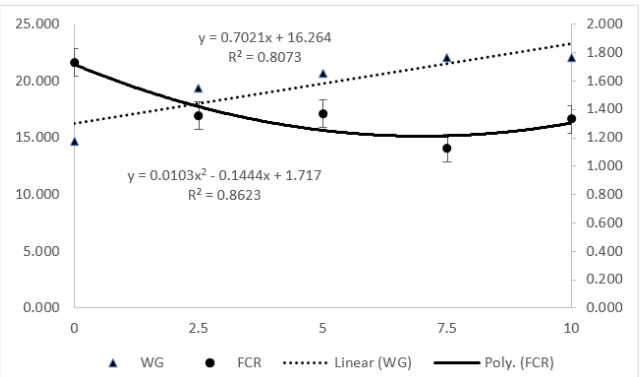

Fig. 2. Regression analysis of body weight gain and feed conversion ratio between increasing the inclusion periphyton addition

The Data of FCR for fish fed different level of dried periphyton fitted a linear model (Fig. 2). FCR $(\mathrm{y})=0.7021 \mathrm{x}+16.264 ; \mathrm{R}^{2}=0.8073$. According to these equations, the best FCR was recorded by fish fed diet 4 which supplemented $7.5 \mathrm{~g}$ dried periphyton $\mathrm{kg}$ 1 .

Table 3. Growth performance of Nile tilapia as affected by different levels of periphyton supplementation

\begin{tabular}{|c|c|c|c|c|c|c|c|}
\hline \multirow{2}{*}{ Items } & \multicolumn{5}{|c|}{ Experimental diets } & \multirow{2}{*}{ SME } & \multirow{2}{*}{ P-values } \\
\hline & Diet 1 & Diet 2 & Diet 3 & Diet 4 & Diet 5 & & \\
\hline $\mathrm{IBW}^{1}\left(\mathrm{~g} \mathrm{fish}^{-1}\right)$ & 6.64 & 6.91 & 6.82 & 7.17 & 7.06 & 0.147 & 0.625 \\
\hline $\mathrm{FBW}^{2}\left(\mathrm{~g} \mathrm{fish}^{-1}\right)$ & $21.7^{\mathrm{c}}$ & $26.3^{b}$ & $28.1^{\mathrm{ab}}$ & $28.8^{\mathrm{a}}$ & $28.8^{\mathrm{a}}$ & 0.568 & 0.025 \\
\hline $\mathrm{WG}^{3}\left(\mathrm{~g} \mathrm{fish}^{-1}\right)$ & $15.06^{\mathrm{c}}$ & $19.38^{\mathrm{b}}$ & $21.27^{\mathrm{a}}$ & $21.63^{\mathrm{a}}$ & $21.74^{\mathrm{a}}$ & 0.465 & 0.001 \\
\hline $\operatorname{SGR}^{4}\left(\%\right.$, day fish $\left.{ }^{-1}\right)$ & $1.97^{\mathrm{c}}$ & $2.22^{\mathrm{b}}$ & $2.35^{\mathrm{a}}$ & $2.31^{\mathrm{ab}}$ & $2.34^{\mathrm{a}}$ & 0.028 & 0.021 \\
\hline Survival rate $\%$ & 81.66 & 86.67 & 86.66 & 93.35 & 95.0 & 5.34 & 0.002 \\
\hline Feed intake $\mathrm{g}$ fish $^{-1}$ & $24.80^{\mathrm{b}}$ & $26.20^{\mathrm{ab}}$ & $27.35^{\mathrm{ab}}$ & $26.25^{\mathrm{ab}}$ & $29.20^{\mathrm{a}}$ & 0.862 & 0.002 \\
\hline Feed conversion ratio & $1.65^{\mathrm{a}}$ & $1.35^{\mathrm{b}}$ & $1.29^{\mathrm{b}}$ & $1.22^{\mathrm{b}}$ & $1.34^{\mathrm{b}}$ & 0.071 & 0.009 \\
\hline Protein efficiency ratio & $2.02^{\mathrm{b}}$ & $2.46^{\mathrm{ab}}$ & $2.59^{\mathrm{a}}$ & $2.75^{\mathrm{a}}$ & $2.48^{\mathrm{ab}}$ & 0.140 & 0.042 \\
\hline
\end{tabular}




\subsection{Chemical composition}

Table 4 showed the chemical composition of wholebody fish as affected by dietary levels of periphyton. No significant differences $(\mathrm{P}>0.05)$ were found in all chemical composition; dry matter, crude protein, crude lipid and ash content of tilapia fed different level of dried periphyton.

\section{Discussion}

In recent years, functional diet supplementation has become a topic of interest for improving not only growth rate and feed utilization but also health status of farmed fish (Tiengtam et al., 2015). Periphyton have a good nutritional value (Table 2) could be considered it appropriate for fish feed (Azim et al., 2002). Chemical composition of the dried periphyton in this study within the same range which noted by Azim et al. (2005) Van Dam et al. (2002) except crude protein was slightly lower varies from 23 to $30 \%$ protein, 2-9\% lipid, 25-28\% NFE and 16-42\% ash. The nutritional value of dried periphyton indicated that periphyton qualifies to be supplemented in the aquatic diets especially, Nile tilapia which need 35 to $25 \%$ protein and up to $6 \%$ lipid (Hassaan et al., 2015).

In the present study, dietary of dried periphyton addition at $7.5 \mathrm{~g}$ and $10 \mathrm{~g} \mathrm{~kg}^{-1}$ (diet 4 and diet 5) significantly $(\mathrm{P}<0.05)$ improved the performance of growth, FCR, PER and survival of Nile tilapia compared with control diet. To the best of our author knowledge, this is the first report study the effect of dried periphyton supplementation in tilapia feed. However, feeding with algae such as periphyton improved growth and survival rate shrimp Penaeus monodon (Anand et al., 2013) and L. vannamei (Ju et al. 2009). On the other hand, periphytic algae could enhances the nutritional quality of penaeid shrimp (Audelo-Naranjo et al., 2011). Saker et al. (2015) reported that fresh periphyton are considered a good source of protein of tilapia and could decrease the protein level of tilapia diet up to $20 \%$ crude protein without negative effect on growth and feed utilization. experimental diets in this trial were isonitrogenous and isocaloric, thus the increase in growth may be associated with the promoting of periphyton such as different of source of chlorophylls (Anad et al., 2013). Microalgae and heterotrophic bacteria have a lot of bioactive compounds (Ju et al., 2009), source of immune activated (Supamattaya et al., 2005), feeding stimulants (Xu et al., 2012) and promoting of growth (Kuhn et al., 2010) which be useful for growth performance of aquatic animal cultured. Furthermore, there are especially vitamins, minerals in periphyton (Anand et al., 2014). Hence, it can be inferred that these beneficial effects of algae and microbes in the periphyton might have attributed to improved growth response in tilapia. Anand et al. (2013) noted that higher level $(9 \%)$ of dried periphyton in Penaeus monodon diet decreased had a negative effect on growth and feed utilization. also, the same finding was showed by Liao et al. (1993) who fed shrimp on diet containing high level of spirulina which causes impair in WG and FCR of $P$. monodon. These negative effects of high inclusion levels of algae may be due to deficiency in the amino acid or trace elements micro (Supamattaya et al., 2005). However, higher feed utilization was showed in $P$. japonicus fed diet supplemented with algal without cell wall than with cell walls (Boonyaratpalin et al., 2001). These results may be due to the lake of endogenous enzyme secretion that degrade the cell walls of algae (Tangerås, and Slinde 1994), thus high inclusion level in aquatic feed resulted in poor digestibility (Halver and Hardy, 2002). Roohani et al. (2019) reported that addition of spirulina at level $8 \%$ could improve the growth performance of juvenile Caspian brown trout (Salmo trutta caspius). It is likely that this dried microalga is more suitable for tilapia enhancing their growth performance. Yeganeh and Adel (2019) reported that the growth performances of great sturgeon $H$. huso juveniles was significantly higher in diets supplemented with Sargassum ilicifolium. Also, dietary supplementation of Spirulina platensis significantly improved performance of growth of great sturgeon (Adel et al. 2016). Similarly, Asino et al. (2011) have shown that dietary supplementation of Ulva Enteromorpha prolifera improved weight gain of Pseudosciaena crocea. Supplementation with red alga Palmaria palmata did not affect weight gain of Atlantic salmon up to $15 \%$ (Wan et al., 2016).

Periphyton have another benefit for Nile tilapia feed, it could be improved protein utilization of feed (Saker et al., 2015) whereas protein efficiency ratio and protein productive value were significantly higher in fish diet containing $20 \%$ and $15 \%$ crude protein with fresh periphyton than without periphyton. The nutritional value of microalgae sometimes is higher than traditional plant protein (Becker 2007) and ratio of protein/ metabolizable energy ratio ranged from 10 - $40 \mathrm{~kg}^{-1}$ (Van Dam et al., 2002). In addition to supplementing the total amount of protein available to the fish, Mridula et al. (2005) suggest that periphyton ingestion increases enzyme activities of intestinal and hepatopancreatic protease, lipase, and intestinal amylase in tilapia fingerlings. On the other hand, grazing on periphyton considering simple technology for decreasing the cost of production (Milstein et al., 2009; Saker et al., 2015). Furthermore, high inclusion level of periphyton increase the ash content which might have resulted into lower feed intake resulting in non-significantly lower growth rate and higher FCR in shrimp received diet with high inclusion levels (Anand et al., 2013). Therefore, physical or chemical treatment might have better to improve the nutritional value of periphyton for aquatic feed While, in our study high 
supplementation level $10 \mathrm{~g} \mathrm{~kg}^{-1}$ having positive effects on growth and physiological responses. However, due to the components periphyton, the causes of growth stimulation for tilapia not clear, but may be due to the improved the digestibility of nutrient and increase the beneficial flora in gastrointestinal. Thus, further studies needed in this context, especially tilapia fish to clear the best levels of supplementation without negative effect.

Table 4. Chemical composition (\%) of whole Nile tilapia as affected by different levels of periphyton supplementation

\begin{tabular}{lccccccc}
\hline \multirow{2}{*}{ Items } & \multicolumn{9}{c}{ Experimental diets } & \multirow{2}{*}{ SME } & P- values \\
\cline { 2 - 6 } & Diet 1 & Diet 2 & Diet 3 & Diet 4 & Diet 5 & & \\
\hline Dry matter & 73.2 & 72.36 & 73.36 & 74.60 & 74.32 & 0.147 & 0.625 \\
Crude protein & 58.23 & 59.23 & 59.3 & 59.61 & 60.06 & 0.578 & 0.325 \\
Crude lipid & 23.12 & 23.12 & 22.12 & 23.18 & 23.91 & 0.433 & 0.801 \\
Ash & 15.40 & 16.13 & 15.9 & 16.13 & 16.14 & 0.428 & 0.521 \\
\hline
\end{tabular}

- Values $( \pm \mathrm{SE}, \mathrm{N}=3)$. Means in within same row sharing the same superscript are not significantly different $(\mathrm{P}>0.05)$.

\section{References}

Adel, M., Yeganeh, S., Dadar, M., Sakai, M., and Dawood, M. A. ,2016. Effects of dietary Spirulina platensis on growth performance, humoral and mucosal immune responses and disease resistance in juvenile great sturgeon (Huso huso Linnaeus, 1754). Fish and shellfish immunology, 56, 436-444.

Anand, P.S., Kumar, S., Panigrahi, A., Ghoshal, T., Dayal, J.S., Biswas, G., Sundaray, J., De, D., Raja, R.A. and Deo, A., 2013. Effects of C: $\mathrm{N}$ ratio and substrate integration on periphyton biomass, microbial dynamics and growth of Penaeus monodon juveniles. Aquaculture International, 21, 511-524.

Anand, S, P. S., Kohli M.P.S., Dam Roy, S, Sundaray J.K., Sujeet Kumar, Archana Sinha, Pailan, G.H., and Munil kumar Sukham 2014. Effect of dietary supplementation of periphyton on growth performance and digestive enzyme activities in Penaeus monodon. Aquaculture, 392-395, 59-68.

AOAC, 1995. In: Cunni, P.A. (Ed.), Official Methods of Analysis of the Association Official Analytical Chemists, Vol. 1, 16th ed. AOAC International, Arlington, USA, p. 1298.

Asaduzzaman, M., Wahab, M. A., Verdegem, M. C. J., Benerjee, S., Akter, T., Hasan, M. M., Azim, M. E., 2009. Effects of addition of tilapia, Oreochromis niloticus and substrates for periphyton developments on pond ecology and production in $\mathrm{C} / \mathrm{N}$-controlled freshwater prawn Macrobrachium rosenbergii farming systems. Aquaculture, 287(3-4), 371-380.

Asino, H., Ai, Q., Mai, K. 2011. Evaluation of Enteromorpha prolifera as a feed component in large yellow croaker (Pseudosciaena crocea, Richardson, 1846) diets. Aquaculture Research, 42(4), 525-533.

Audelo-Naranjo, J. M., Martínez-Córdova, L. R., Voltolina, D., Gómez-Jiménez, S. 2011. Water quality, production parameters and nutritional condition of Litopenaeus vannamei (Boone, 1931) grown intensively in zero water exchange mesocosms with artificial substrates. Aquaculture Research, 42(9), 1371-1377.

Azim, M.E., Asaeda, T., Verdegem, M.C.J., Van Dam, A.A., and Beveridge, M.C.M., 2005. Periphyton structure, diversity and colonization. In: Azim, M.E., Verdegem, M.C.J., van Dam, A.A., Beveridge, M.C.M. (Eds.), Periphyton: Ecology, Exploitation and Management. CABI publishing, UK, pp. 207-222.

Azim, M.E., Verdegem, M.C.J., Khatoon, H., Wahab, M.A., Van Dam, A.A. and Beveridge, M.C.M., 2002. A comparison of fertilization, feeding and three periphyton substrates for increasing fish production in freshwater pond aquaculture in Bangladesh. Aquaculture, 212, 227-243

Becker, E. W., 2007. Microalgae as a source of protein. Biotechnology Advances 25:207-210.

Brett, J. R. 1973. Energy expenditure of Sockeye salmon Oncorhynchus nerka, during sustained performance. Journal of the Fish Research Board of Canada, 30: 1799-1809.

Boonyaratpalin, M., Thongrod, S., Supamattaya, K., Britton, G., Schlipalius, L. E. 2001. Effects of $\beta$ carotene source, Dunaliella salina, and astaxanthin on pigmentation, growth, survival and health of Penaeus monodon. Aquaculture Research, 32, 182-190.

Boyd, C. E. 1990. Water quality in Ponds for Aquaculture. Alabama Agriculture. Experiment Station, Auburn University, Alabama.

Duncan, M. B. 1955. Multiple ranges and multiple Ftests. Biometrics, 11:1-42.

FAO 2018. The state of world fisheries and aquaculture 2018 - meeting the sustainable development goals.

Fawole, F. J., Sahu, N. P., Pal, A. K., \& Ravindran, A. 2016. Haemato-immunological response of $\mathrm{L}$ abeo rohita ( $\mathrm{H}$ amilton) fingerlings fed leaf extracts and challenged by Aeromonas hydrophila. Aquaculture Research, 47(12), 37883799. 
Halver, J.E., Hardy, R.W., 2002. Fish Nutrition, 3rd ed. Academic Pr, p. 807.

Hassaan, M. S., Mohammady, E. Y., Adnan, A. M., Abd Elnabi, H. E., Ayman, M. F., Soltan, M. A., El-Haroun, E. R., 2020. Effect of dietary protease at different levels of malic acid on growth, digestive enzymes and haemato-immunological responses of Nile tilapia, fed fish meal free diets. Aquaculture, 522, 735124.

Hassaan, M.S., Soltan, M.A. and Abdel-Moez, A.M., 2015. Nutritive value of soybean meal after solid state fermentation with Saccharomyces cerevisiae for Nile tilapia (Oreochromis niloticus). Anim. Feed Sci. Technol., 201:89-98.

Ju, Z.Y., Forster, I.P. and Dominy, W.G., 2009. Effects of supplementing two species of marine algae or their fractions to a formulated diet on growth, survival and composition of shrimp (Litopenaeus vannamei). Aquaculture, 292, 237243

Keshavanath, P., Gangadhar, B., Ramesh, T. J., Van Dam, A. A., Beveridge, M. C. M., Verdegem, M. C. J., 2002. The effect of periphyton and supplemental feeding on the production of the indigenous carps Tor khudree and Labeo fimbriatus. Aquaculture, 213(1-4), 207-218.

Liao,W.L., Borhan, N.E., Okada, S.A., Matsui, S., Yamaguchi, K.,1993. Pigmentation of cultured black tiger prawn (Penaeus monodon) by feeding with a Spirulina-supplemented diet. Japanese Society of Scientific Fisheries 59, 165-169

Menanteau-Ledouble, S., Krauss, I., Santos, G., Fibi, S., Weber, B., El-Matbouli, M. 2015. Effect of a phytogenic feed additive on the susceptibility of Onchorhynchus mykiss to Aeromonas salmonicida. Diseases of aquatic organisms, 115(1), 57-66.

Milstein, A., Y. Peretz, and S. Harpaz., 2009. Culture of organic tilapia to market size in periphyton based ponds with reduced feed inputs. Aquaculture Research 40:55-59.

Mridula, R. M., J. K. Manissery, P. Keshavanath, K. M. Shankar, M. C. Nandeesha, and K. M. Rajesh., 2005. Effects of paddy straw and sugarcane bagasse on water quality, bacterial biofilm production and growth and survival of rohu, Labeo rohita (Hamilton). Aquaculture Research 36:635-642.
Roohani, A. M., Abedian Kenari, A., Fallahi Kapoorchali, M., Borani, M. S., Zoriezahra, S. J., Smiley, A. H., Rombenso, A. N. 2019. Effect of spirulina Spirulina platensis as a complementary ingredient to reduce dietary fish meal on the growth performance, whole-body composition, fatty acid and amino acid profiles, and pigmentation of Caspian brown trout (Salmo trutta caspius) juveniles. Aquaculture Nutrition, 25(3), 633-645.

Sakr, E. M., Shalaby, S. M., Wassef, E. A., El-Sayed, A. F. M., Moneim, A. I. A. (2015). Evaluation of periphyton as a food source for Nile Tilapia (Oreochromis niloticus) juveniles fed reduced protein levels in cages. Journal of Applied Aquaculture, 27(1), 50-60.

Supamattaya, K., Kiriratnikom, S., Boonyaratpalin, M., and Borowitzka, L., 2005. Effect of Dunaliella extract on growth performance, health condition, immune response and disease resistance in black tiger shrimp (Penaeus monodon). Aquaculture 248, 207-216.

Tangerås, A., Slinde, E. 1994. Coloring of salmonids in aquaculture: the yeast Phaffia rhodozyma as a source of astaxanthin. In Fisheries Processing (pp. 391-431). Springer, Boston, MA.

Tiengtam, N., Khempaka, S., Paengkoum, P., and Boonanuntanasarn, S., 2015. Effects of inulin and Jerusalem artichoke (Helianthus tuberosus) as prebiotic ingredients in the diet of juvenile Nile tilapia (Oreochromis niloticus). Animal Feed Science and Technology, 207, 120-129.

Van Dam, A.A., Beveridge, M.C.M., Azim, M.E., and Verdegem, M.C.J., 2002. The potential of fish production based on periphyton. Reviews in Fish Biology and Fisheries, 12, 1-31

Wan, A. H., Soler-Vila, A., O'Keeffe, D., Casburn, P., Fitzgerald, R., \& Johnson, M. P. (2016). The inclusion of Palmaria palmata macroalgae in Atlantic salmon (Salmo salar) diets: effects on growth, haematology, immunity and liver function. Journal of Applied Phycology, 28(5), 3091-3100.

Yeganeh, S., and Adel, M., 2019. Effects of dietary algae (Sargassum ilicifolium) as immunomodulator and growth promoter of juvenile great sturgeon (Huso huso Linnaeus, 1758). Journal of Applied Phycology, 31(3), 2093-2102 